\title{
PERSONALITY PSYCHOLOGY
}

\section{An Existential Criterion for the Normal and Abnormal Personality in the Works of Viktor Frankl. Summary}

\author{
Sergey A. Kapustin ${ }^{*}$ \\ Lomonosov Moscow State University, Moscow, Russia \\ *Corresponding author. E-mail: skapustin@mail.ru
}

Background. This is the last in a series of four articles scheduled for publication in this journal. In the first article (Kapustin, 2015a), I proposed a new "existential criterion" for the normal and abnormal personality that is implicitly present in the works of Erich Fromm. According to this criterion, normal and abnormal personalities are determined, first, by their position regarding existential dichotomies, and, second, by particular aspects of the formation of this position. Such dichotomies, entitatively existent in human life, are inherent, two-alternative contradictions. In the other articles (Kapustin, 2015b, 2016a), I showed that this criterion is also implicitly present in the four famous personality theories of Freud, Adler, Jung, and Rogers.

Objectives. To provide evidence that this criterion is present in the personality theory of Viktor Frankl and to present a comparative analysis of all six theories of personality.

Results. The existential criterion for the normal and abnormal personality based on the works of Fromm is also implicitly present in theoretical conceptualizations of personality, predisposed and non-predisposed to developing various psychological problems and to mental disorders, by Freud, Adler, Jung, Rogers, and Frankl, although in more particular forms, related to more specific existential dichotomies, characterizing the nature of human life.

Conclusion. The fact that the existential criterion is present in these six theories of personality, developed within totally different approaches to psychology and psychotherapy, is evidence of a high degree of its theoretical justification and of the possibility of their integration.

Keywords:

human nature, human essence, existential dichotomy, normal personality, abnormal personality 


\section{Introduction}

In the first article in this series (Kapustin, 2015a), I described an "existential criterion" for the normal and abnormal personality implicitly present in the works of Erich Fromm (1942, 1947, 1964, 1977, 1991).

Fromm developed his theoretical understanding of personality based on the philosophical branch of objective humanistic ethics, which proposes a certain view of how a human being should live. The ultimate moral imperative of a person who is following what should be considered as a standard of life, involves the self-determination of values that facilitate living in accordance with human nature.

Based on this school of thought, Fromm proposed his own theoretical concept of human nature, which has two characteristics that Fromm considered essential. The first is that in human life there are so-called existential dichotomies, which are inherent, two-alternative contradictions, which appear to a person as problems requiring solution. The second characteristic is that a human being is capable of self-determination.

The most important concepts in Fromm's works are those of the productive and the nonproductive personality, which are characterized by particular features of the content and the formation of the personality in relation to these two characteristics. Fromm defined this position as a scheme of orientation and worship. If the position of a personality (scheme of orientation and worship) in its content and in the way it is formed facilitates implementation of these two characteristics, such a personality was defined by Fromm as productive; if not, it is nonproductive. From the point of view of objective humanistic ethics, the way of life of a productive personality is a norm of human life, because it corresponds to human nature. Thus a productive personality can be considered a normal personality; a nonproductive personality deviates from this norm and is abnormal.

In my view, because Fromm considers the essence of human life to be characterized by existential dichotomies and self-determination, the position of a productive (normal) personality is compromising in its content, matching the contradictory structure of human life in the form of existential dichotomies, and it is created by oneself, based on one's life experience and reason-that is, on a rational basis. On the contrary, the nonproductive (abnormal) personality denies the contradictive structure of human life in the form of existential dichotomies, and is oriented toward a consistent, noncompetitive and, as a consequence, one-sided way of life. A specific feature of this position is that it is imposed by others and based on a person's wishes and feelings about them - that is, on an irrational basis. From the point of view of Fromm, the abnormality of a personality interpreted like that is one of the most important factors influencing the development of various psychological problems and other mental disorders-primarily, neurosis.

Given that the criterion for differentiating between normal and abnormal personalities involves specific features of their position toward existential dichotomies, I identify this criterion as existential: Normality and abnormality are determined first by special features of content and second by particular aspects of the formation of a position toward existential dichotomies, which are entitatively existent in human life and are inherent, two-alternative contradictions that appear to a person as problems requiring solution. 
The essential attribute of a normal personality is orientation toward the contradictory predetermination of life in the form of existential dichotomies and the need to search for compromise in their resolution. A distinct feature of the formation of this position is that it develops on a rational basis with the active participation of the person-that is, on the basis of knowledge, the source of which is the person's own experience and reason. The position of an abnormal personality subjectively denies the contradictious predetermination of life in the form of existential dichotomies and is oriented toward a consistent, noncompetitive, and, as a consequence, onesided way of life that doesn't include self-determination. Such a position is imposed by other people on an irrational basis: that of wishes for and feelings toward them.

The objectives of my articles were to show that the existential criterion is contained in a number of well-known theories of personality developed in different traditions of psychology and psychotherapy and regarded as incompatible with each other. In the second article in this series (Kapustin, 2015b), I showed that this criterion is implicitly present in the personality theory of Sigmund Freud (1963a, $1963 \mathrm{~b}, 1964)$, toward the existential dichotomy of nature-culture, and in the personality theory of Alfred Adler $(2007,2011)$ toward the existential dichotomy of superiority-community. In the third article (Kapustin, 2016a), I showed that this criterion is also implicitly present in the personality theory of Carl Jung (1914, $1969,1971,1972)$, toward the existential dichotomy of opposites, and in the personality theory of Carl Rogers $(1959,1965,1995)$, toward the existential dichotomy of self-actualization-conditional values.

\section{Objectives}

The objectives of this article are to show that the new existential criterion of normal and abnormal personality based on the works of Fromm is implicitly present in the theories of personality of Viktor Frankl, although in a rather special way, and to present a comparative analysis of all six theories of personality.

\section{The Existential Criterion in Frankl's Theory of Personality}

I begin discussing Frankl's theory $(1967,1986,1990,2014)$ with an analysis of his general views on human nature, which he views as characterized by a pluralism of diverse forms of existence that coexist in life as an indestructible unity:

The distinguishing characteristic of human existence is the coexistence between anthropological unity and ontological differences, between the unified human manner of being and the diverse constitutive elements of being of which it is a part. (Frankl, 1990, p. 48)

Frankl explains this view with a geometrical analogy. Pluralism of diverse forms of human existence can be compared to an integral dimensional figure, presented on a chart as three projections in orthogonal dimensions. Each of these projections, taken separately, characterizes some essential feature of this geometrical figure, but only one-sidedly, because a dimensional figure cannot be identified as only one of its projections. Adequate and full representation of the form exists only in the unity of its diverse projections. 
According to Frankl, the main different forms of human existence, equivalent to three orthogonal dimensions in geometry, are the biological, social, and spiritual. Each of these forms is characterized by its specific features.

The biological form of human existence characterizes human life as a living organism. In Frankl's view, this is a subject of research mostly in two sciences: biology and psychology. The social form of human existence characterizes life in society and is studied in the field of sociology. Frankl considers these three sciences, which study human life in two important dimensions, as bearing a certain resemblance: All three of them study people from the perspective of the natural sciences, regarding them as creatures whose lives are fully conditioned and predetermined. For example, in biology there are attempts to explain human behavior with the help of innate predisposition. According to Frankl, examples of this approach are the theory of Freud, in which human behavior is explained by sexual drives, and that of Adler, which explains human behavior by the person's character. Sociologists often regard social conditions of various kinds as the most important determinants of human life.

In Frankl's view, such positions cannot be appropriate due to their one-sidedness. Natural scientists' approach misses the most important human dimension, the most important characteristics that compose mankind's essence: spirituality, freedom, and responsibility:

Spirituality, freedom, and responsibility are the three constituents of human existence. They do not only characterize human existence as the existence of a person in particular; rather they constitute it as such. In this sense, human spirituality is not a characteristic, but a constitutive feature: The spiritual is not just inherent to human beings as physical and mental, qualities which are inherent to animals as well. The spiritual is a distinctive feature of the human being, which is inherent to him and only to him. Naturally, an airplane does not cease to be an airplane if it moves only on the ground. It can, and indeed must, move on the ground over and over again, but that it really is an airplane only becomes evident when it lifts off into the sky. (Frankl, 1990, p. 93)

Let's discuss these three characteristics in further detail.

In Frankl's view, there are phenomena of so-called facultative noö-psychic antagonism (phenomena of the obstinacy of the human spirit), which testify to a specific spiritual origin. They consist of the ability to withstand one's own natural predetermination by taking a certain position toward one's life and to act in accordance with this position, despite the pressure of social circumstances, drives, heredity, and other such natural determinants. Explaining his vision of the existence of a spiritual origin in a person, Frankl writes:

Human existence is conditioned. Though it becomes human only then and because, when and because it goes beyond its own conditioning, overcoming it, "transcending" it. Thus a person is a person only then and because, when and because he goes beyond the limits of his physical and mental existence as a spiritual creature.... Nevertheless we want to emphasize the fact that man as a spiritual creature not only withstands the world (external as well as inner), but also takes a position toward it. A person may always somehow "have an attitude toward", "behave" in relation to the world. At every 
moment of his life, a person takes a certain position in relation to his natural and social environment, to the external world as well as to the vital psychophysical inner world, inner environment. And that which is able to withstand the social, physical and even mental in man, is what we call spiritual in him. (Frankl, 1990, pp. 111-112)

As a psychiatrist, Frankl states that facultative noö-psychic antagonism has crucial significance in the human struggle for recovery from mental illness. In his view, mental illness often has a psychophysical nature, but that doesn't mean that a person cannot withstand it. On the contrary, "in order to cure himself, the patient needs to somehow distance himself internally from his disease, his 'madness' " (Frankl, 1990, p. 113). He sees one of the most important tasks of a therapist in:

facilitating development of a healthy distance, which allows the patient as a spiritual personality due to facultative noö-psychic antagonism to take a position with regard to psychophysical disease, a very important position from the therapeutic perspective! Because this inner distance, taken by the spiritual in relation to the psychophysical, which is the foundation of the noö-psychic antagonism, seems to us very fruitful in relation to therapy. Eventually, any psychotherapy should be based on noö-psychic antagonism. (Frankl, 1990, pp. 113-114)

Man as a spiritual creature has freedom, which makes him capable of self-determination. Explaining his vision of this second specifically human characteristic, Frankl points at the two aspects of human freedom-negative and positive-which he calls "freedom from" and "freedom to" (Frankl, 1986, p. 52).

The negative aspect characterizes man as someone relatively independent from his natural predetermination. This means that his life journey cannot be fully determined by biological, psychological, and social determinants; he can actively participate in the determination of his life. At the same time, Frankl emphasizes that human independence is quite relative and should not be seen as omnipotence. Independence is possible only within a certain range, which is limited by the objective conditions of human life. In one of his works, Frankl points at this relatively negative human freedom, saying that

there is little point in opposing the "power of spirit" to the "power of nature". We have already indicated that both are contingent upon one another in his existence. For man is a citizen of more than one realm; he stands in life in a state of permanent tension, in a bipolar field of force. If we attempted to pit the two powers against one another, to test the power of one against the power of the other, the result would probably be a "dead hit". As is well known, a dead hit is the liveliest kind of race. The eternal combat between man's spiritual freedom and his inward and outward destiny is what intrinsically makes up his life. (Frankl, 1986, p. 82)

The positive aspect of human freedom is, according to Frankl, closely connected to the third essential human characteristic: responsibility. Frankl gives a substantial description of this characteristic in the form of answers to the questions that he poses to himself: 1) What does a person take responsibility for? 2) 
Before what does a person take responsibility? 3) Before whom does a person take responsibility?

Answering the first question, Frankl emphasizes that human spiritual existence is always a conscious existence, and human responsibility consists of finding the sense of one's life, as a whole as well as in the particular circumstances. Meaning is given to life by values. A person must find these values by himself, and then his positive freedom lies in the freedom of choice of these values.

Before what does a person take responsibility? Before his conscience, which is closely related to the success in fulfilling his main moral duty. In Frankl's view, this duty is to be human, which means to be spiritual, free, and responsible-i.e., self-determinant in the values of one's own life and their implementation. Frankl believes that human nature is made so that man's conscience is able to indicate his advance or failure in fulfilling his main moral duty.

Answering the question, before whom does a person take responsibility, Frankl, being a believer, points at God as the Creator of man. It cannot be otherwise for a true believer, because if man is created by God, in the image and likeness of God, he is responsible for his specifically human existence, which, when all is said and done, passes before the face of God.

Thus, in general the specific character of human spiritual existence can be determined as a constantly conscious existence, which is a result of human self-determination on the questions of the values of his own life, for which he is responsible before his conscience and his Creator.

The existential criterion for normal and abnormal personality is implicitly present in the works of Frankl in his theoretical conceptualization of personality, non-predisposed and predisposed, respectively, to developing various psychological problems and mental disorders. Normality and abnormality (non-predisposition and predisposition to developing psychological problems of different kinds and to mental disorders) of a personality in Frankl's theory are determined by the particular features of the position a person takes toward his life.

Frankl defines the position of abnormal personality as fatalistic, because it orients the person's attitude to himself as to a naturally predetermined creature, which lacks a specifically human spiritual dimension. A person with such a position does not regard himself as responsible for the self-determination of his values, and, as a consequence, doesn't see himself as an active participant and allows various natural, psychological, and social determinants to decide his life journey.

According to Frankl, the most common consequence of human life following this fatalistic position is the development of a particular state, which he calls an existential vacuum. This vacuum is characterized by the experience of emptiness in life, boredom, loss of the meaning of life, lack of interest in life. According to a survey he conducted at the Medical University, Vienna, where he worked, symptoms of this state were found in $40 \%$ of Austrian, West German, and Swiss students, and in $80 \%$ American students. Frankl regards the existential vacuum as a prerequisite of various mental and behavioral disorders.

The position of a normal personality above all orients the person toward his spiritual existence, which implies awareness of responsibility for the meaningful- 
ness of one's life. A person with a normal personality brings into effect the meanings of life, which he finds by himself, thus becoming an active participant in forming the direction of his own life. At the same time, a normal personality is also conscious of being conditioned by various biological, psychological, and social factors, which predetermine a human life, regardless of the person's own will. Due to this position of the normal personality, there is a reasonable compromise between naturally predetermined biological and social human existence, and free and reliable spiritual existence.

Frankl repeatedly emphasized the need for such compromise. For instance, he uses an illustrative comparison:

An individual's destiny belongs to him in much the same way as the ground, which fetters him by its gravity, but without which walking would be impossible. We must accept our destiny as we accept the ground on which we stand-a ground which is the springboard for our freedom. Freedom without destiny is impossible; freedom can only be freedom in the face of a destiny, a free stand toward destiny. Certainly man is free, but he is not floating freely in airless space. He is always surrounded by a host of restrictions. These restrictions, however, are the jumping-off points for his freedom. Freedom presupposes restrictions, is contingent upon restrictions. (Frankl, 1986, p. 75)

In Frankl's view, the conscious position of a normal personality toward life should be formed fully independently, and this idea is accentuated in his characterization of the main goal and process of existential psychotherapy:

Existential analysis, along with all forms of medical ministry, is content and must be content with leading the patient to the experience in depth of his own responsibility. Continuation of the treatment beyond that point, so that it intrudes into the personal sphere of particular decisions, must be termed impermissible. The physician should never be allowed to take over the patient's responsibility; he must never permit that responsibility to be shifted to himself; he must never anticipate decisions or impose them upon the patient. His job is to make it possible for the patient to reach decisions; he must endow the patient with the capacity for deciding. (Frankl, 1986, pp. 276-277)

Comparing the theories of personality of Frankl and Fromm, we conclude that they have two similar provisions.

First, one of the most important statements in Frankl's theory is his assertion of a contradiction between different forms of human existence: On one side, a person should live according to his biological and social nature, as a naturally predetermined creature, and follow natural, psychological, and social influences of different kinds. On the other side, man, as a creature responsible for the self-determination of life's meanings, should live in accordance with his spiritual nature. Due to the fact that such contradictions are inevitable from the very nature of human life, we may regard it as an existential dichotomy in Fromm's terms and define it as a dichotomy of determinism-self-determination. 
Second, the existential criterion for the normal and abnormal personality is implicitly present in Frankl's theoretical concept of personality, non-predisposed and predisposed, respectively, to developing psychological problems and mental illnesses, and is characterized by the same particular features of content and formation of the position of the individual, as in Fromm's theory of personality, but in relation to this more specific existential dichotomy.

The normal personality orients the person toward the contradictiory predetermination of life in the form of an existential dichotomy of determinism-selfdetermination. A person with such a position is conscious of the unity of the diverse forms of his existence and admits the necessity of his simultaneous existence in all these forms. As a result, his position is one of reasonable compromise. Such a person admits that he is responsible for self-determination of the meanings of his own life, taking into account his real abilities, dictated by the biological and social conditions of his life. The position of the normal personality is developed on a rational basis, with the active participation of the person himself. It is done in the process of self-cognition, first of all of cognition of his own spiritual existence.

The position of the abnormal personality, called fatalistic, in its content orients a person toward a one-sided attitude toward himself, as if to a naturally predetermined creature who should obediently accept his fate and refuse responsibility for self-determination of the meanings of his own life. Frankl doesn't elaborate on the specific features of the formation of such a fatalistic position. Nevertheless, proceeding from its substantial characteristic, which fully corresponds to its name, we may conclude that it is not a result of self-determination, because it radically denies such a possibility.

Thus, the existential criterion for the normal and abnormal personality based on the works of Fromm is also implicitly present in Frankl's theory of personality as being non-predisposed and predisposed, respectively, to developing various psychological problems and other mental disorders. Frankl's theory, however, is based on the special case of an existential dichotomy of determinism-self-determination.

\section{Summary: Comparative Study of Criteria for the Normal and Abnormal Personality in the Works of Fromm, Freud, Adler, Jung, Rogers, and Frankl}

The results of the theoretical study discussed here and in the previous works (Kapustin, 2015a, 2015b, 2016a) allow the following conclusions.

1. Based on the works of Fromm, we propose a new "existential criterion" for the normal and abnormal personality, implicitly present in his works. According to this criterion, these two types of personality are determined by the particular content and the formation of a person's position toward existential dichotomies. Such dichotomies, entitatively existent in one's life, are inherent two-alternative contradictions between its different sides. They appear to the individual as problems requiring solution. This criterion is shown in the Table 1 as the three main differences. 
Table 1

Existential criterion for the normal and abnormal personality

\begin{tabular}{|c|c|c|}
\hline & \multicolumn{2}{|c|}{$\begin{array}{c}\text { Characteristics of the position taken by a person toward } \\
\text { existential dichotomies }\end{array}$} \\
\hline & Normal personality & Abnormal personality \\
\hline $\begin{array}{l}\text { Content } \\
\text { of the position }\end{array}$ & $\begin{array}{l}\text { Compromising: } \\
\text { orients toward a contradictory prede- } \\
\text { termination of life in the form of ex- } \\
\text { istential dichotomies and the necessity } \\
\text { of searching for compromise in resolv- } \\
\text { ing them }\end{array}$ & $\begin{array}{l}\text { One-sided: } \\
\text { orients toward a consistent, non-com- } \\
\text { petitive and, as a consequence, one- } \\
\text { sided way of life, denying the contradic- } \\
\text { tiory predetermination of human life in } \\
\text { the form of existential dichotomies }\end{array}$ \\
\hline \multirow[b]{2}{*}{$\begin{array}{l}\text { Formation } \\
\text { of the position }\end{array}$} & $\begin{array}{l}\text { On one's own: } \\
\text { result of self-determination }\end{array}$ & $\begin{array}{l}\text { Imposed: } \\
\text { formed by others }\end{array}$ \\
\hline & $\begin{array}{l}\text { Rational: } \\
\text { based on one's own experience and } \\
\text { reason }\end{array}$ & $\begin{array}{l}\text { Irrational: } \\
\text { based on wishes and feelings }\end{array}$ \\
\hline
\end{tabular}

2. This criterion is also implicitly present in the theoretical conceptualizations of personality, predisposed and non-predisposed to developing various life problems and to mental disorders, by Freud, Adler, Jung, Rogers, and Frankl, though, in more particular forms, related to more specific existential dichotomies characterizing human life. These dichotomies are listed in Table 2.

Table 2

Existential dichotomies in different theories of personality

\begin{tabular}{ll}
\hline \multicolumn{1}{c}{ Author } & \multicolumn{1}{c}{ Characteristics of human life } \\
\hline Erich Fromm & Existential dichotomies \\
Sigmund Freud & An existential dichotomy of nature-culture \\
Alfred Adler & An existential dichotomy of superiority-community \\
Carl Jung & Existential dichotomies of opposites \\
Carl Rogers & An existential dichotomy of self-actualization-conditioned values \\
Viktor Frankl & An existential dichotomy of determinism-self-determination \\
\hline
\end{tabular}

As shown in Table 3, the position of a normal personality orients the person toward contradictory predetermination of his life in the form of existential dichotomies and the necessity of searching for compromise in their resolution. The position of an abnormal personality orients the individual one-sidedly toward implementation of only one side of this dichotomy in his life, denying the need for implementation of another and, by doing so, directs the person to a non-confrontational and non-competitive way of life.

As shown in Table 4, in all these theories the position of a normal personality develops with the active participation of the person on a rational basis. At the same 
time, these theories emphasize an important role of self-cognition in forming such a position and accentuate the specific features of self-cognition. We have not found any direct information about the formation of a position of the abnormal personality in the theories of Jung and Frankl. But in the other theories, where such information is present, it is stated that such a position is imposed on a person in early childhood, on an irrational basis, by internal or external sources, and the content of such an irrational basis is discussed in detail.

Table 3

Criteria for normal and abnormal personalities in different theories of personality, based on the content of the position taken by the individual toward existential dichotomies

\begin{tabular}{|c|c|c|}
\hline \multirow{2}{*}{ Author } & \multicolumn{2}{|c|}{ Content of the position } \\
\hline & Normal personality & Abnormal personality \\
\hline Erich Fromm & $\begin{array}{l}\text { Orients toward a contradictory pre- } \\
\text { determination of life in the form of } \\
\text { existential dichotomies and the ne- } \\
\text { cessity of searching for compromise } \\
\text { in resolving them }\end{array}$ & $\begin{array}{l}\text { Orients toward a consistent, non- } \\
\text { competitive, and, as a consequence, } \\
\text { one-sided way of life, denying its } \\
\text { contradictory predetermination in } \\
\text { the form of existential dichotomies }\end{array}$ \\
\hline Sigmund Freud & $\begin{array}{l}\text { Orients toward a contradictiory pre- } \\
\text { determination of life in the form of } \\
\text { a dichotomy of nature-culture and } \\
\text { the search for compromise in resolv- } \\
\text { ing it }\end{array}$ & $\begin{array}{l}\text { Orients one-sidedly toward follow- } \\
\text { ing cultural taboos on certain ob- } \\
\text { jects of natural (sexual) drives and } \\
\text { ways of satisfying them, denying the } \\
\text { existence of these prohibited drives } \\
\text { in oneself }\end{array}$ \\
\hline Alfred Adler & $\begin{array}{l}\text { Orients toward a contradictory pre- } \\
\text { determination of life in the form of } \\
\text { a dichotomy of superiority-commu- } \\
\text { nity and the search for compromise } \\
\text { in resolving it }\end{array}$ & $\begin{array}{l}\text { Orients one-sidedly toward gaining } \\
\text { superiority over other people and } \\
\text { denying the realization of a feeling } \\
\text { of community }\end{array}$ \\
\hline Carl Jung & $\begin{array}{l}\text { Orients toward a contradictory pre- } \\
\text { determination of life in the form of } \\
\text { existential dichotomies of opposites } \\
\text { and the search for compromise in } \\
\text { resolving them }\end{array}$ & $\begin{array}{l}\text { Orients one-sidedly toward the real- } \\
\text { ization of conscious attitudes, deny- } \\
\text { ing the need for realization of their } \\
\text { unconscious opposites }\end{array}$ \\
\hline Carl Rogers & $\begin{array}{l}\text { Orients toward a contradictory pre- } \\
\text { determination of life in the form of } \\
\text { an existential dichotomy of self-ac- } \\
\text { tualization-conditional values and } \\
\text { the search for compromise in resolv- } \\
\text { ing it }\end{array}$ & $\begin{array}{l}\text { Orients one-sidedly toward aligning } \\
\text { one's personal qualities with condi- } \\
\text { tional values, denying the need for } \\
\text { self-actualization }\end{array}$ \\
\hline Viktor Frankl & $\begin{array}{l}\text { Orients toward a contradictory pre- } \\
\text { determination of life in the form of } \\
\text { a dichotomy of determinism-self- } \\
\text { determination and the search for } \\
\text { compromise in resolving it }\end{array}$ & $\begin{array}{l}\text { Orients one-sidedly toward obedi- } \\
\text { ence to fate, denying responsibility } \\
\text { for self-determination of the mean- } \\
\text { ings of one's own life }\end{array}$ \\
\hline
\end{tabular}


Table 4

Criteria of the normal and abnormal personality in different theories of personality, based on formation of the position taken by the individual toward existential dichotomies

\begin{tabular}{|c|c|c|}
\hline \multirow{2}{*}{ Author } & \multicolumn{2}{|l|}{ Formation of the position } \\
\hline & Normal personality & Abnormal personality \\
\hline Erich Fromm & $\begin{array}{l}\text { Developed with the active participa- } \\
\text { tion of the person himself on a ration- } \\
\text { al basis - on knowledge, the source of } \\
\text { which is his own experience and rea- } \\
\text { son }\end{array}$ & $\begin{array}{l}\text { Imposed by other people on an irra- } \\
\text { tional basis - on the wishes and feel- } \\
\text { ings that he experiences toward them }\end{array}$ \\
\hline Sigmund Freud & $\begin{array}{l}\text { Developed with the active participa- } \\
\text { tion of the person himself on a rational } \\
\text { basis - in the process of self-cognition, } \\
\text { first of all, of cognition of one's uncon- } \\
\text { scious }\end{array}$ & $\begin{array}{l}\text { Imposed by other people in one's } \\
\text { childhood on an irrational basis, using } \\
\text { one's vital and psychological depend- } \\
\text { ence on them }\end{array}$ \\
\hline Alfred Adler & $\begin{array}{l}\text { Developed with the active participa- } \\
\text { tion of the person himself on a rational } \\
\text { basis - in the process of self-cognition, } \\
\text { first of all, of cognition of one's leading } \\
\text { motivation and individual style of life }\end{array}$ & $\begin{array}{l}\text { Imposed in childhood on an irrational } \\
\text { basis, under the influence of an exa- } \\
\text { gerated feeling of inferiority }\end{array}$ \\
\hline Carl Jung & $\begin{array}{l}\text { Developed with the active participa- } \\
\text { tion of the person himself on a rational } \\
\text { basis - in the process of self-cognition, } \\
\text { first of all, of cognition of one's person- } \\
\text { al and collective unconscious }\end{array}$ & No direct evidence \\
\hline Carl Rogers & $\begin{array}{l}\text { Developed with the active participa- } \\
\text { tion of the person himself on a rational } \\
\text { basis - in the process of self-cognition, } \\
\text { first of all, of cognition of one's dis- } \\
\text { torted conscious and unconscious ex- } \\
\text { perience }\end{array}$ & $\begin{array}{l}\text { Imposed in childhood by other people } \\
\text { on an irrational basis - on the basis of } \\
\text { the person's need for positive regard } \\
\text { from others and for positive self-re- } \\
\text { gard }\end{array}$ \\
\hline Viktor Frankl & $\begin{array}{l}\text { Developed with the active participa- } \\
\text { tion of the person himself -on a ra- } \\
\text { tional basis, in the process of self-cog- } \\
\text { nition, first of all, of cognition of one's } \\
\text { own spiritual existence }\end{array}$ & No direct evidence \\
\hline
\end{tabular}

\section{Conclusion}

1. The fact that an existential criterion for the normal and abnormal personality is present in six classical theories of personality, developed within totally different approaches to psychology and psychotherapy, is evidence of a relatively high degree of its theoretical justification. If we also take into account that all these theories were based on analysis of clinical cases from the psychotherapeutic practice of their authors, this criterion can be considered as having a relatively high degree of empirical justification. 
2. The general provisions found in all these theories of personality indicate the possibility of their integration, although they were developed in different approaches to psychology and psychotherapy that are traditionally regarded as incompatible.

3. These results allow us to draw the general conclusion that the existential criterion can be successfully used to assess the abnormality of a personality as one of the most important indicators of its predisposition to developing various life problems and mental disorders, as well as in the practice of psychotherapy, in the correction and education of the personality, as one of the most valuable reference points for its normal development.

\section{Application of the Results}

I have shown in a number of empirical studies (Kapustin, 2014, 2015c, 2015d, 2015e, 2016d) that the key factor leading to child-parent problems in the families of clients in psychological consultation is the abnormality of the parents' personalities, identified through an "existential criterion" that is displayed in their parenting styles. These parenting styles contribute to the development of children with abnormal personality types, also identified through existential criteria, that are designated as "oriented toward external help", "oriented toward compliance of one's own behavior with other people's requirements", and "oriented toward protest against compliance of one's own behavior with other people's requirements".

Children with such personality types are faced with requirements from their closest social environment that are appropriate for children with normal personalities, but not for those with abnormal personal abilities, and so they start having problems. As these problems are connected with difficulty adjusting to requirements of the social environment, they can be classified as problems of social adaptation.

I have identified a similarity between the personality type "oriented toward compliance of one's own behavior with other people's requirements" and theoretical concepts in the work of Fromm, Freud, Adler, Jung, Rogers, and Frankl about the predisposition of people with an abnormal personality to various psychological problems and mental disorders. These similarities suggest that a personality of this type can be regarded as a classic type that all these authors faced in their psychotherapeutic practices. It was shown that abnormal personality types, formed in childhood, influenced the formation of a large proportion of personal and marital problems in adulthood (Kapustin, 2016b, 2016c).

\section{References}

Adler, A. (2007). The science of living. New York, NY: Meredith Press.

Adler, A. (2011). The practice and theory of individual psychology. Bensenville, IL: Lushena Books.

Frankl, V.E. (1967). Psychotherapy and existentialism: Selected papers on logotherapy. New York, NY: Washington Square Press, Inc. https://doi.org/10.1037/h0087982

Frankl, V.E. (1986). The doctor and the soul: From psychotherapy to logotherapy. New York, NY: Random House.

Frankl, V.E. (1990). Chelovek v poiskah smysla: Sbornik [Man's search for meaning: Selected works]. Moscow: Progress. 
Frankl, V.E. (2014). The will to meaning: Foundations and applications of logotherapy. New York, NY: Penguin/Plume.

Freud, S. (1963a). Introductory lectures on psycho-analysis (pts. 1 \& 2). In J. Strachey (Ed. \& Trans.). The standard edition of the complete psychological works of Sigmund Freud (Vol. 15, pp. 1-242). London: The Hogarth Press and the Institute of Psycho-analysis.

Freud, S. (1963b). Introductory lectures on psycho-analysis (pt. 3). In J. Strachey (Ed. \& Trans.). The standard edition of the complete psychological works of Sigmund Freud. (Vol. 16, pp. 243-483). London: The Hogarth Press and the Institute of Psycho-Analysis.

Freud, S. (1964). New introductory lectures on psycho-analysis and other works. In J. Strachey (Ed.). The standard edition of the complete psychological works of Sigmund Freud. (Vol. 21, pp. 1-184. London: The Hogarth Press and the Institute of Psycho-analysis.

Fromm, E. (1942). Fear of freedom. London: K. Paul, Trench, Trubner \& Co., Ltd.

Fromm, E. (1947). Man for himself. An inquiry into the psychology of ethics. New York: Rinehart and Co.

Fromm, E. (1964) The heart of man: Its genius for good and evil. San Francisco: Harper \& Row.

Fromm, E. (1977). To have or to be? New York, NY: Continuum.

Fromm, E. (1991) On being human. London: Bloomsbury Academic \& Professional.

Jung, C. G. (1914). On the importance of the unconscious in psychopathology. British Medical Journal, 2(2814), 964-968.

Jung, C. G. (1969). Approaching the unconscious. In Man and his symbols. New York, NY: Doubleday.

Jung, C. G. (1971). On the relation of analytical psychology to poetry. In The spirit in man, art, and literature (vol. 15 of The collected works of C. G. Jung). Princeton, NJ: Princeton University Press.

Jung, C. G. (1972). Two essays on analytical psychology. Princeton, NJ: Princeton University Press.

Kapustin, S.A. (2014). Stili roditel'skogo vospitaniya v sem'yah klientov psikhologicheskoi konsul'tatsii po detsko-roditel'skimi problemami [Styles of parenting in families of clients who have sought psychological counseling for parent-child problems]. Vestnik Moskovskogo universiteta. Seriya 14. Psikhologiya [Bulletin of Moscow University. Series 14. Psychology], 4, 76-90. http://msupsyj.ru/articles/detail.php?article $=5225$

Kapustin, S.A. (2015a). An existential criterion of normal and abnormal personality in the works of Erich Fromm. Psychology in Russia: State of the Art, 8(2), 87-98. https://doi.org/10.11621/pir.2015.0208

Kapustin, S.A. (2015b). An existential criterion of normal and abnormal personality in the works of Sigmund Freud and Alfred Adler. Psychology in Russia: State of the Art, 8(3), 4-16. https://doi.org/10.11621/pir.2015.0301

Kapustin, S.A. (2015c). Ispol'zovanie ekhzistentsial'nogo kriteriya dlya otsenki lichnosti giperopekayushchih i sverkhtrebovatel'nyh roditelei v sem'yah klientov psikhologicheskoi konsul'tatsii po detsko-roditel'skim problemam [The use of an existential criterion for assessing personality of hyperprotective and overly demanding parents in families of clients who have sought psychological counseling for parent-child problems]. Vestnik Moskovskogo universiteta. Seriya 14. Psikhologiya [Bulletin of Moscow University. Series 14. Psychology], 2, 51-62. https://doi.org/10.11621/vsp.2015.02.51

Kapustin, S.A. (2015d). Osobennosti lichnosti detei v sem'yah klientov psikhologicheskoi konsul'tatsii [Personal features of children in families of clients who have sought psychological counseling]. Natsional'nyi psikhologicheskii zhurnal [National Psychological Journal], 1(17), 79-87. https://doi.org/10.11621/npj.2015.0109

Kapustin, S.A. (2015e). Sbalansirovannyi stil' roditel'skogo vospitanie i ego vliyanie na razvitie lichnosti detei [Balanced parenting style and its impact on the development of the child's personality]. Natsional'nyi psikhologicheskii zhurnal [National Psychological Journal], 4(20), 119-129. https://doi.org/10.11621/npj.2015.0412

Kapustin, S.A. (2016a). The existential criterion of normal and abnormal personality in the works of Carl Jung and Carl Rogers. Psychology in Russia: State of the Art, 9(2), 54-68. https://doi.org/10.11621/pir.2016.0205 
Kapustin, S.A. (2016b). Ispol'zovanie rezul'tatov issledovaniya semei s detsko-roditel'skimi problemami v praktike psikhologicheskogo konsul'tirovaniya vzroslykh lyudei [Using the results of the study of families with parent-child problems in a practice that counsels adults]. Vestnik Moskovskogo universiteta. Seriya 14. Psihologiya [Bulletin of Moscow University. Series 14. Psychology], 1, 79-95. https://doi.org/10.11621/vsp.2016.01.79

Kapustin, S.A. (2016c). Vliyanie giperopeki (sverkhtrebovatel'nosti) na vozniknovenie supruzheskikh problem [Influence of hyperprotection (overexactness) on marital problems]. Natsionalnyi psikhologicheskii zhurnal [National Psychological Journal], 1(21), 62-69. https://doi.org/10.11621/npj.2016.0108

Kapustin, S.A. (2016d). Using the existential criterion for assessing the personality of overprotective and overly demanding parents in the families of patients who have sought psychological counseling for parent-child problems. Russian Education and Society, vol. 58, 4, 247-259, 2016. https://doi.org/10.1080/10609393.2016.1250489

Rogers, C.R. (1959). A theory of therapy, personality and interpersonal relationships as developed in the client-centered framework. In S. Koch (Ed.), Psychology: A study of a science (vol. 3, pp. 184-256). New York, NY: McGraw-Hill Book Company, Inc.

Rogers, C.R. (1965). Client-centered therapy: Its current practice, implications, and theory. Boston: Houghton Mifflin.

Rogers, C.R. (1995). On becoming a person: A therapist's view on psychotherapy. Boston: Houghton Mifflin.

Original manuscript received April 02, 2018

Revised manuscript accepted September 24, 2019

First published online June 25, 2020

To cite this article: Kapustin, S.A. (2020). An Existential Criterion for the Normal and Abnormal Personality in the Works of Viktor Frankl. Summary. Psychology in Russia: State of the Art, 13(2), 140-153. DOI: $10.11621 /$ pir.2020.0210 